\title{
Synaptic dimorphism in Onychophoran cephalic ganglia
}

\author{
Z. Peña-Contreras ${ }^{1}$, R.V. Mendoza-Briceño ${ }^{1}$, L. Miranda-Contreras ${ }^{1}$, E.L Palacios-Prü ${ }^{1}$ \\ 1 Centro de Microscopía Electrónica. University of the Andes, Calle 32, Mérida, Venezuela; prupal@ula.ve
}

Received 21-XI-2003. Corrected 18-IV-2006. Accepted 13-X-2006.

\begin{abstract}
The taxonomic location of the Onychophora has been controversial because of their phenotypic and genotypic characteristics, related to both annelids and arthropods. We analyzed the ultrastructure of the neurons and their synapses in the cephalic ganglion of a poorly known invertebrate, the velvet worm Peripatus sedgwicki, from the mountainous region of El Valle, Mérida, Venezuela. Cephalic ganglia were dissected, fixed and processed for transmission electron microscopy. The animal has a high degree of neurobiological development, as evidenced by the presence of asymmetric (excitatory) and symmetric (inhibitory) synapses, as well as the existence of glial cell processes in a wide neuropile zone. The postsynaptic terminals were seen to contain subsynaptic cisterns formed by membranes of smooth endoplasmic reticulum beneath the postsynaptic density, whereas the presynaptic terminal showed numerous electron transparent synaptic vesicles. From the neurophylogenetic perspectives, the ultrastructural characteristics of the central nervous tissue of the Onychophora show important evolutionary acquirements, such as the presence of both excitatory and inhibitory synapses, indicating functional synaptic transmission, and the appearance of mature glial cells. Rev. Biol . Trop. 55 (1): 261-267. Epub 2007 March. 31.
\end{abstract}

Key words: Onychophora, synapses, Peripatus, ultrastructure, cephalic ganglia, evolution.

An ongoing study of great interest in our laboratory is focused on the investigation of the nervous tissue natural history and, in particular, the occurrence of primitive morphological characteristics of nerve cells that contributed to the increasing complexity of nervous tissue in higher phyla of multicellular organisms. As part of this study, we analyzed the ultrastructure of the nervous system of a poorly known invertebrate, Peripatus sedgwicki (phylum Onychophora).

The taxonomic location of the phylum Onychophora, also know as "velvet worms", has been controversial because of its phenotypic and genotypic characteristics that are related to both annelids and arthropods, making it difficult to locate this phylum within the zoological scale (Hickman et al. 1994, Strausfeld 1998, Schmidt-Rhaes et al. 1998, Marotta and Ruhberg 2004). While others consider the Onychophora a branch of intermediate evolution between the annelids and arthropods, recent cladistic studies (MongeNájera and Mulberry 1994, Monge-Nájera 1995) eliminate the association of this phylum with the ancestral group of the Unirramia (Manton 1973, Hickman et al. 1994).

Onychophorans have a cylindrical and unsegmented body, with a pair of antennae on its anterior end, one eye at the base of each antenna, and a ventraly located mouth with a well-developed jaw, which represents a modification of the anterior region of the body. This invertebrate shows non-articulated legs, varying in number from 14 to 43 pairs, which remind of the Polychaetus parapodia. Each leg is a thick, conical protuberance with a pair of terminal nails, from where the name of the phylum was coined (Morera-Brenes and MongeNájera 1990, Hickman et al. 1994, Ruppert and 
Barnes 1995). The body is covered by a thin, flexible and highly permeable cuticle, whose chemical composition is similar to that of the arthropods (Hackman and Goldberg 1975).

Onychophorans are predators that eat smaller invertebrates. Their circulatory system is similar to that of the arthropods, and their respiratory system is also formed by windpipes and spiracles (Hickman et al. 1994, Monge-Nájera and Lourenço 1995). The sexes are always separate; there are oviparous, ovoviviparous and viviparous (Walker and Campligia 1998).

From an anatomical point of view, the Onychophoran nervous system is composed of two cerebral masses joined together by a connecting peduncle, and a pair of widely separated longitudinal nerve cords connected by transversal commissures extending all along the length of the body (Hickman et al. 1994, Storch and Ruhberg 1993). Nerve fibers leave the cephalic region and extend toward the antennae; they also emerge out from the nerve cords to innervate the paws and the body wall. They possess sensory papillae, pigmented ocellus, tactile spines around the mouth, tactile papillae on the body surface and eyes with structural features that remind those of the annelids more than the ocellus of the arthropod; some species have a lens and a cup composed of receptor neurons, each one having a photoreceptor process (Bullock and Horridge 1965).

The goal of the present study was to analyze the ultrastructure of the neurons and their synapses in the cephalic ganglion of this Venezuelan species in order to investigate the evolutionary acquisition of nervous tissue, particularly differential characteristics indicative of their neurological development.

\section{MATERIALS AND METHODS}

Animals: in this work, P. sedgwicki, was chosen as a representative of the phylum of Onychophora. Six animals (four male and two female) hand collected by E. PalaciosPrü in February, 2 000, 2150 m.a.s.l., in the mountainous area of El Valle Grande,
Mérida, Venezuela, rain forest $\left(8^{\circ} 35^{\prime} 18^{\prime \prime} \mathrm{N}\right.$ and $71^{\circ} 09^{\prime} 43$ " W). The cephalic ganglion, located at the anterior region, was dissected under microscopic observation, fixed and then processed for transmission electron microscopy.

Electron Microscopy: the cephalic ganglion was immersed for six hours, at $4{ }^{\circ} \mathrm{C}$, in a $0.1 \mathrm{M}$ cacodylate-buffered mixture of $3 \%$ glutaraldehyde and 3\% formaldehyde $(\mathrm{pH} 6.3)$ (Palacios-Prü and Mendoza 1972). The tissues were then rinsed three times in $0.1 \mathrm{M}$ cacodylate buffer and postfixed for 12 hours in $1 \%$ osmium tetroxide prepared in the same buffer, at $4{ }^{\circ} \mathrm{C}$. The fixed tissues were dehydrated in graded ascending ethanolic solutions followed by propylene oxide and finally embedded in Epon 812. Thin sections of $90 \mathrm{~nm}$ were stained following the classic methods of Reynolds (Reynolds 1963), Watson (Watson 1958) and modification of Sato's method (Hanaichi et al. 1986), and then observed with a Hitachi H-7000 electron microscope for ultrastuctural analysis.

\section{RESULTS}

The cephalic ganglion of the P. sedgwicki constitutes a well-differentiated neuronal mass located at the anterior region of the animal and is formed by two lobules joined together by a narrow tissular formation or istmus. At low magnification, it is possible to observe the cellular components of the cephalic ganglion and its relation with the nearby tissular elements (Fig. 1). Although there is not structure that defines the limits of the ganglion, the tissues surrounding the ganglion form an encapsulation. Under the epithelium, a series of subepidermic tissues are easily identifiable: first, a layer of connective tissue, then a layer of tissue with a porous aspect and which also contains cellular processes of muscle cells; more internally, a layer of mostly pigmented cells is located adjacent to the bilobuled cephalic ganglion.

The cephalic ganglion of Onychophora showed a high level of neurobiological 


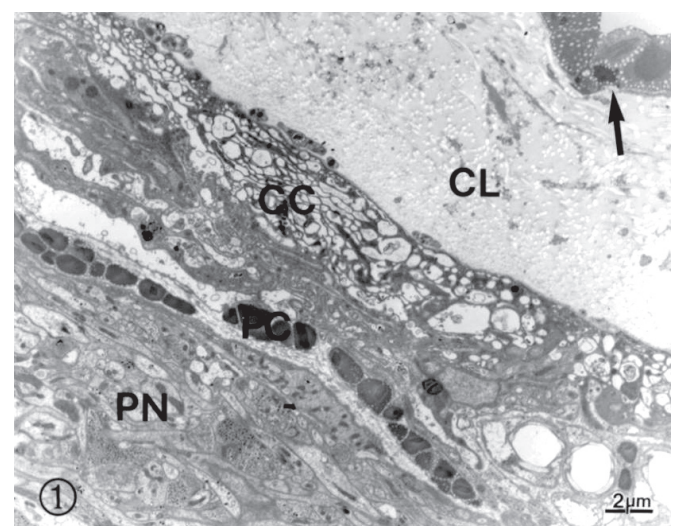

Fig. 1. In this micrograph, part of the neuropile zone (PN) of the cephalic ganglion can be observed, including the cells surrounding the ganglion, such as pigmented cells (PC) and cribose cells (CC) as well as the conjunctive layer (CL), which constitutes the tissular limit of the ganglion. Arrow indicates the epidermal cells forming the external limit of the epidermal complex of these animals. 4 800X.

development. As shown in figures 1 and 2, two well-defined regions could easily be identified: the first is a wide neuropile zone located at the anterodorsal region of the ganglion and in which numerous synapses could be observed (Fig. 2); the second, localized at the posterolateral region of the ganglion, showed a predominance of neuronal cell bodies with a high production of vesicles, both dense-cored neurosecretory and electron transparent synaptic vesicles (Fig. 2) (Geffen and Jarrot 1977, Peters et al. 1991, Palacios-Prü et al. 1998). Most of the neurons showed reduced cytoplasm and large, elongated nuclei with peripheral and central accumulations of dense heterochromatin (Fig. 2). In the cytoplasm, abundant golgiosomes are frequently observed constituted by various flat discs extending from the central region toward the periphery, where vesiculogenesis occurs. In this zone, numerous forming vesicles are usually seen (Fig. 3). In some cases, the golgiosomes are observed associated with contractile cytoskeleton, as shown in Fig. 3.

Numerous asymmetric and symmetric chemical synapses, corresponding to the excitatory and inhibitory synapses, respectively, were seen in the neuropile region. As can be observed in Fig. 4, the presynaptic element of

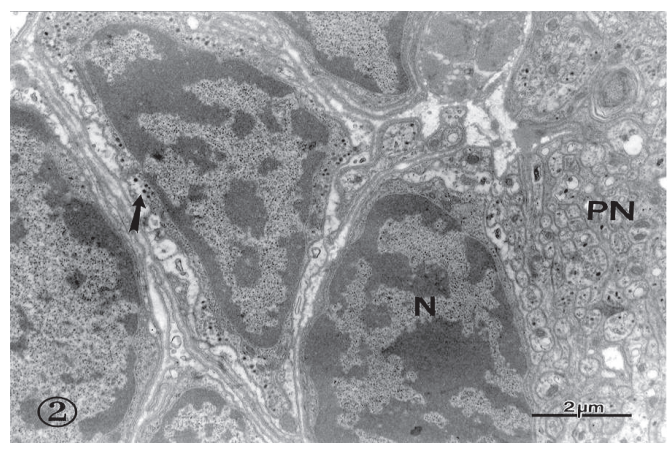

Fig. 2. Inside the cephalic ganglion can be seen neuronal cell bodies with large nucleus $(\mathrm{N})$ and dense chromatin, and in their thin cytoplasm, abundant electron-dense neurosecretory vesicles (arrow) can be observed. Part of the peripheral neuropile zone $(\mathrm{PN})$ of the ganglion is shown on the left of the micrograph. $9600 \mathrm{X}$.

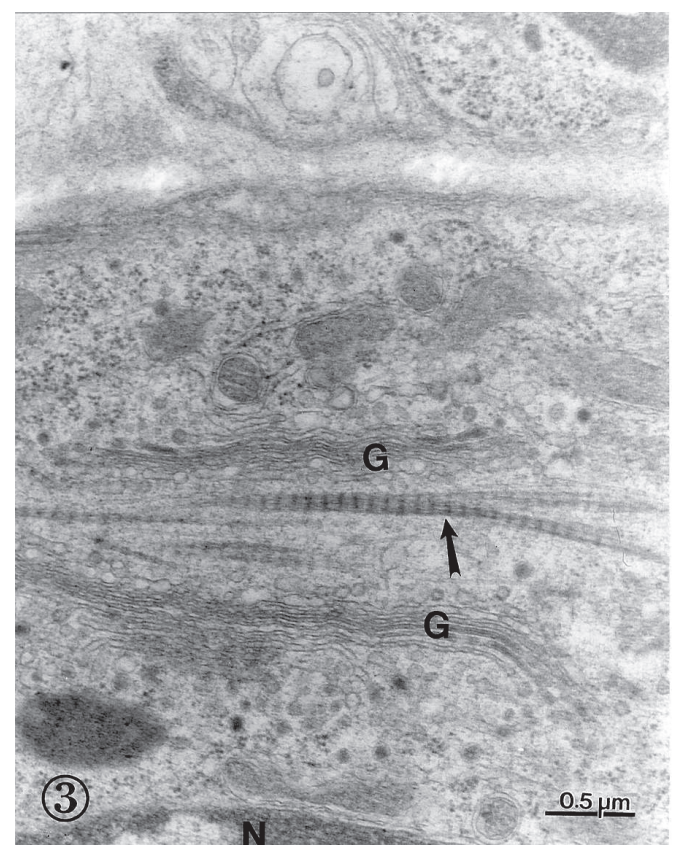

Fig. 3. Cytoplasm of a neuron where two golgiosomes (G) are seen in active phase of neurosecretory vesicle production. Around the Golgi complex are observed longitudinal structures of clear and dark bands showing periodicity similar to the contractile radicules of the cytoskeleton (arrow). Nucleus (N), 32 000X.

the asymmetric synapse contained abundant electron-transparent synaptic vesicles, which were mostly round and accumulated at the synaptic active sites. Some dense-cored vesicles, of larger diameter than the synaptic vesicles, 


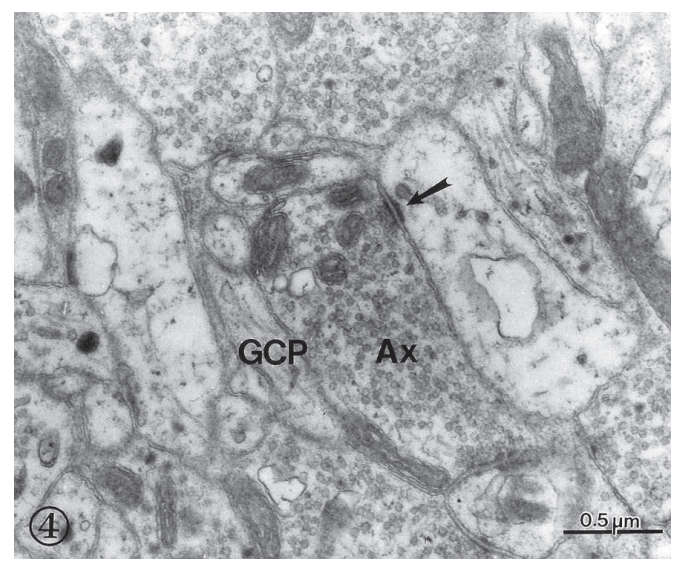

Fig. 4. In this micrograph are shown axons (Ax) containing abundant electron-transparent synaptic vesicles and some electron-dense neurosecretory vesicles, asymmetric and symmetric chemical synapses (arrow). Glial cell processes (GCP) can also be observed surrounding the axons. $32000 X$.

and small mitocondria were also seen in the presynaptic terminals. The postsynaptic element showed a well-constituted, thick postsynaptic density, which is the characteristic ultrastructural feature of this component of the synaptic complex.

Symmetric chemical synapses, corresponding to the inhibitory synapses, showed a well-organized presynaptic grid at the synaptic active zone and rigidity in both pre-and postsynaptic membranes, making this area of the synaptic complex more straight and of higher electron-density; at the postsynaptic site, no appreciable postsynaptic density was observed (Fig. 5). The majority of the synaptic vesicles seen in these synapses are small, electrontransparent and, although some are round, most of them are irregular in shape.

In the cephalic ganglion of the Onychophora, the presence of subsynaptic cisterns formed by membranes of smooth endoplasmic reticulum was observed beneath the postsynaptic density. As shown in figures 6 and 7, dense cytoplasm could be seen at the area of the receptor element. In this type of synapse, a higher density of synaptic vesicles was observed adhered at the presynaptic active zone. Glial cell

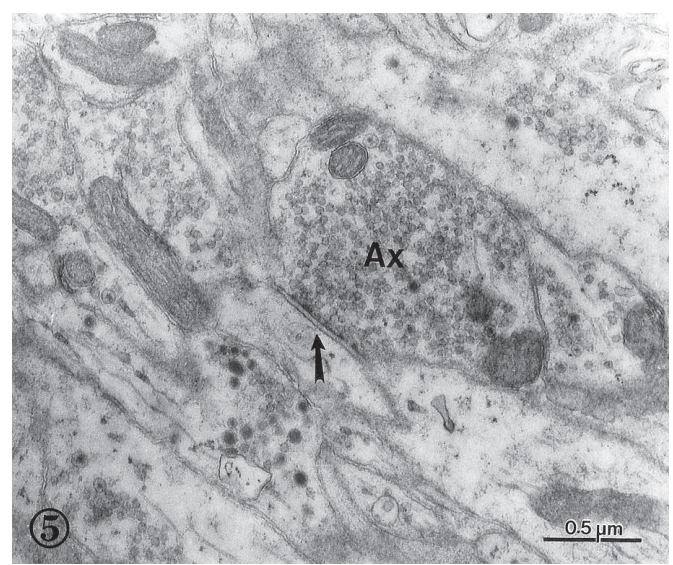

Fig. 5. In this image can be observed symmetric or inhibitory synapses. Arrow indicates the absence of postsynaptic density at the postsynaptic site and at the presynaptic membrane, presynaptic grid is clearly seen. Notice that at the synaptic active site, the pre- and postsynaptic membranes are arranged in a rectilinear manner. Axon (Ax). 28 800X.

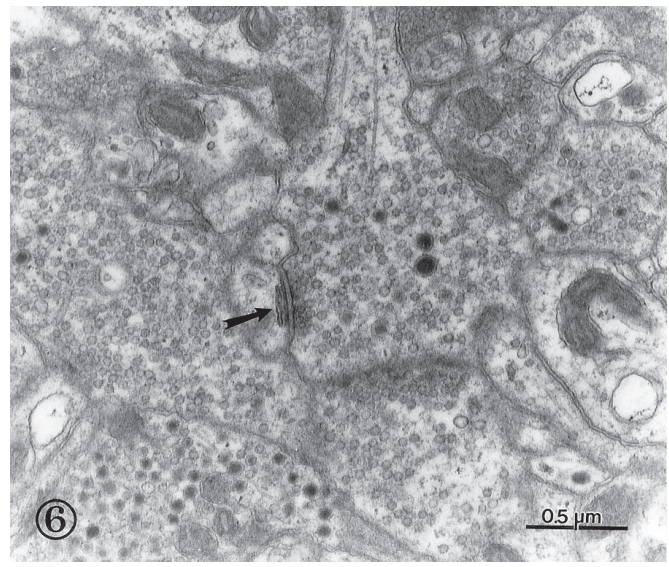

Fig. 6. Segment of the neuropile region where asymmetric synapses are seen containing abundant electron-transparent synaptic vesicles and some electron-dense neurosecretory vesicles. An asymmetric synapse is shown with the subsynaptic cisterns clearly observed in the postsynaptic element (arrow). 28 800X.

processes (Fig. 7) were easily identifiable due to the presence of filaments similar to those seen in more complex animals (Palay and Chan-Palay 1977 ) in terms of the neurophylogenesis. In Fig. 7, glial cell processes tend to surround and separate groups of neuronal elements. 


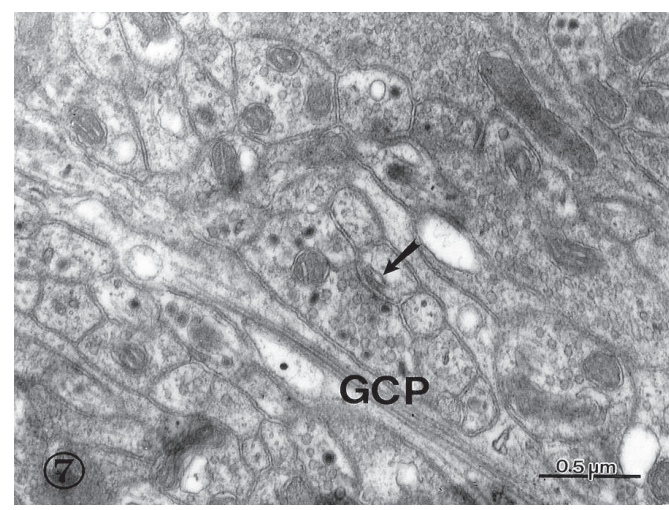

Fig. 7. In this micrograph of the neuropile region, an axon terminal is shown forming an asymmetric synapse, where a slightly dilated subsynaptic cistern (arrow) is observed within the postsynaptic element. Glial cell processes (GCP) are also seen surrounding some axons. 28 800X.

\section{DISCUSSION}

The results obtained in this study may have low significant taxonomical importance but we are convinced that they contribute to know the onset of ultrastructural characteristics that reveal some of the steps of the evolution of the CNS. In this study, our main interest was to demonstrate the high level of neurobiological development of the Onychophora, as shown by the presence of cephalic ganglion, welldifferentiated neurons characterized by a high production of synaptic vesicles, and having a proportionality of their cytoplasm and nucleus very much similar to that of planarian neurons (Reuter 1981, Biserova et al. 2000)

One of the most prominent characteristic of the P. sedgwicki cephalic ganglion is the presence of two principal types of synapses: excitatory and inhibitory, as shown in figures 4 and 5. This fact is an important neuroevolutionary advance, since we did not observe inhibitory synapses in planarians, neither in annelids (Palacios-Prü et al. 2003). In the phylum Onychophora, few ultrastructural differences exist between the synaptic vesicles of the excitatory terminals and the inhibitory ones, however, in synapses that we have classified as inhibitory, that is, lacking postsynaptic densities, the vesicles are more irregular in shape (Fig. 5), similar to those seen in the vertebrate CNS (Peters et al. 1991). The excitatory synapses show both synaptic active sites and postsynaptic densities, as can be observed in Fig. 4, and the synaptic vesicles are spherical and transparent. An important characteristic found in these axon terminals is the presence of very few dense-cored vesicles in contrast with the other studied species (Geffen and Jarrot 1977, Palacios-Prü et al. 1998).

A particular finding in favor of a more advanced degree of evolution of the Onychophora is the presence of subsynaptic cisterns in some of the synaptic contacts observed in the cephalic ganglion of the animals. These subsynaptic cisterns are formed by a membranous apparatus or small cisterns of smooth endoplasmic reticulum (Shürmann 1978) which are found in more evolved nervous tissues, as in vertebrates (Palacios-Prü 1971) and even in some insects such as flies (Strausfeld 1976). In some vertebrate neurons, as the Purkinje cells of the cerebellum, similar structures can be seen in dendritic spines and have been denominated spine apparatus (Gray 1962). According to some investigators, these membranous cisterns contain ions that contribute to the neuronal processes of depolarization and repolarization of the postsynaptic active zones (Callatay 1969, Palacios-Prü 1971).

Another important characteristic demonstrating the more advanced grade of evolution of the nervous tissue in the Onychophora is the presence of glial cell processes, a characteristic which is also found in the annelids. However, these glial cell processes are shorter and more dense while those found in P. sedgwicki are longer and filled with abundant gliofilaments.

All these ultrastructural characteristics, such as the presence of excitatory and inhibitory synapses, a high density of electron transparent synaptic vesicles, subsynaptic cisterns and glial cell elements, are important evolutionary acquisitions demonstrating the importance of Onychophora in the study of neurophylogenesis. 


\section{ACKNOWLEDGMENTS}

We are grateful to Nancy Pacheco, Mauro Nieto, José Ramírez and Henry Picón for their excellent technical assistance. This investigation was partially supported by CDCHT-ULA Grant M-534-95-03-E.

\section{RESUMEN}

Estudiamos la ultraestructura de las neuronas y sus sinapsis del ganglio cefálico de un invertebrado poco conocido del phylum Onychophora: Peripatus sedgwicki de los Andes Venezolanos, utilizando para ello la microscopía electrónica de transmisión. La localización taxonómica de los onicóforos ha sido controversial debido a sus características fenotípicas y genotípicas que los relacionan tanto con los anélidos como con los artrópodos. Para este trabajo se estudió el ganglio cefálico de $P$. sedgwicki de la zona montañosa de El Valle, Mérida, Venezuela. El ganglio cefálico se localiza en la región anterior del animal y fue diseccionado, fijado y luego procesado para microscopía electrónica de transmisión. El estudio ultraestructural permitió observar el alto grado de desarrollo neurobiológico de este grupo. En el ganglio cefálico se observó una amplia zona neuropílica donde se constató la existencia de sinapsis químicas asimétricas y simétricas, las cuales corresponden con sinapsis excitatorias e inhibitorias respectivamente. Se pudo observar en los terminales sinápticos una formación cisternal subsináptica formada por membranas de retículo endoplásmico liso situada por debajo de la densidad postsináptica; también se constató la existencia de prolongaciones gliales en la región de neuropila. Todas las características descritas demuestran, desde la perspectiva de la neurofilogénesis, que el estudio del tejido nervioso central de los onicóforos presenta importantes adquisiciones evolutivas, como la presencia de terminales axónicos con una significativa densidad de vesículas sinápticas electrón-transparentes, sinapsis excitatorias e inhibitorias y la presencia de cisternas subsinápticas, además de una importante maduración de elementos gliales.

Palabras clave: Onicóforo, sinapsis, Peripatus, ultraestructura, ganglio cefálico, evolución.

\section{REFERENCES}

Biserova, N.H., V.A. Dudicheva, N.B. Terenina, M. Reuter, D.W. Halton, A.G. Maule \& M.K.S. Gustafsson.
2000. The nervous system of Amphilina foliacea (Platyhelminthes: Amphilinidea). An immunocytochemical, ultrastructural and spectrofluorometrical study. Parasitology 121: 441-453.

Bullock, T.H. \& G.A. Horridge. 1965. Structure and function in the nervous systems of invertebrates. Vol.I. W. H. Freeman and Company, San Francisco, California, USA. 798 p.

Callatay, A. 1969. Cerebellum and cerebrum model with periodic processing, neurotubules conduction hypothesis. Curr. Modern Biol. 3: 45-61.

Geffen, L.B. \& B. Jarrot. 1977. Cellular aspects of catecholaminergic neurons, p. 521-572. In J.M. Brookhart \& V.B. Mountcastle (eds.). Handbook of Physiology. Waverly, New York, USA.

Gray, E.G. 1962. A morphological basis for presynaptic inhibition. Nature 193:82-83.

Hackman, R.H. \& M. Goldberg. 1975. Peripatus: Its affinities and its cuticle. Science 190: 582-583.

Hanaichi, T., T. Sato, T. Iwamoto, T. Malavasi-Yamashiro, M. Hoshino \& N. Mizuno. 1986. A stable lead by modification of Sato's method. J. Electron. Microsc. 35: 304-306.

Hickman, C.P., L.S. Roberts \& A. Larson. 1994. Zoología. Principios Integrales. McGraw-Hill, México, DF. $921 \mathrm{p}$.

Manton, S.M. 1973. The evolution of arthropodan locomotory mechanisms. Part 11 . Habits, morphology and evolution of the Uniramia (Onychophora, Myriapoda, Hexapoda) and comparisons with the arachnida, together with a functional review of uniramian musculature. Zool. J. Linn. 53: 257-375.

Marotta, R. \& H. Ruhberg. 2004. Sperm ultrastructure of an ivoparous and ovoviviparous onychophoran species (Peripatopsidae) with some phylogenetic considerations. J. Zool. Syst. Evol. Research. 42: 313-322.

Morera-Brenes, B. \& J. Monge-Nájera. 1990. Epiperipatus hilkae, n. sp. From Costa Rica (Onychophora: Peripatidae). Rev. Biol. Trop. 38: 449-455.

Monge-Nájera, J. 1995. Phylogeny, biogeography and reproductive trends in the Onychophora. Zool. J. Linn. Soc. 114:21-60. 
Monge-Nájera, J. \& B. Mulberry. 1994. Morphological and physiological characteristics of two species of Epiperipatus from Costa Rica (Onychophora: Peripatidae). Rev. Biol. Trop. 42: 181-188.

Monge-Nájera, J. \& W.R. Lourenco. 1995. Biogeographic implications of evolutionary trends in onychophorans and scorpions. Biogeographica 71: 179-185.

Palacios-Prü, E.L. 1971. Aspectos ultraestructurales de la corteza cerebelosa. Estudio comparativo: Roedores y Quirópteros. Método de Golgi y microscopía electrónica. Tesis Doctoral. Universidad de Los Andes. Mérida, Venezuela. 174 p.

Palacios-Prü, E.L.\& R.V. Mendoza. 1972. An unusual relationship between glial cells and neuronal dendrites in olfactory bulbs of Desmodus rotundus. Brain Res. 36: 404-408.

Palacios-Prü, E.L., L. Miranda-Contreras, R.V. MendozaBriceño \& J.R. Lozano-Hernández. 1998. Hypothalamic synaptogenesis and its relationship with the maturation of hormonal secretion. Cell. Mol. Neurobiol. 18: 267-284.

Palacios-Prü, E.L., R.V. Mendoza-Briceño, Z. PeñaContreras, L. Miranda-Contreras, V. Marcano, P. Benítez-Díaz \& I. Sornes-Poleo. 2003. Orígenes de la neurona y las sinapsis, p. 117-144. In E. PalaciosPrü \& V. Marcano (eds.). Astrobiología. Ediciones Centro de Microscopía Electrónica. Universidad de los Andes. Mérida, Venezuela.

Palay, S.L. \& V. Chan-Palay. 1977. General morphology of neurons and neuroglia, p. 5-38. In J.M. Brookhart \& V.B. Mountcastle (eds.). Handbook of Physiology. Waverly, New York, USA.

Peters, A., S.L. Palay \& H. Webster. 1991. The fine structure of the nervous system. Neurons and their supporting cells. Oxford University, New York, USA. 494 p.
Reuter, M. 1981. The nervous system of Microstomum lineare (Turbellaria, Macrostomida). II. The ultrastructure of synapses and neurosecretory release sites. Cell Tissue Res. 218: 375-387.

Reynolds, E.S. 1963. The use of lead citrate at high $\mathrm{pH}$ as an electron-opaque stain in electron microscopy. J. Biophys. Biochem. Cytol. 19: 208-212.

Ruppert, E.E. \& R.D. Barnes. 1995. Zoología de los invertebrados. McGraw-Hill, México, DF. 1114 p.

Schimidt-Rhaes, A., T. Bartolomaeus, C. Lemburg, U. Ehlers \& J.R. Garey. 1998. The position of the arthropoda in the phylogenetic system. J. Morphol. 238: $263-285$.

Strausfeld, N.J. 1976. Atlas of an insect brain. SpringerVerlang, Berlin, Germany. 214 p.

Strausfeld, N.J. 1998. Crustacean-Insect relationships: The use of brain characters to derive phylogeny amongst segmented invertebrates. Brain Behav. Evol. 52: 186-206.

Shürmann, F.W. 1978. A note on the structure of synapses in the ventral nerve cord of the onychophoran Peripatoides leukarti. Cell Tissue Res. 186: 527-534.

Storch, V. \& H. Ruhberg. 1993. Onychophora, p. 11-56. In F.W. Harrison \& M.E. Rice (eds.). Microscopic Anatomy of Invertebrates. Wiley, New York, USA.

Walker, M.H. \& S.S. Campligia. 1998. Seminal receptacula in gravid and virgin female Peripatus (Macroperipatus) acacioi Marcus and Marcus (Onychophora: Peripatidae). J. Morphol. 237: 127-136.

Watson, H.L. 1958. Staining of tissue sections for electron microscopy with heavy metals. J. Biophys. Biochem. Cytol. 4: 475-478. 
